\title{
The Role of Community Radio in Medium, Small and Micro Enterprises (MSMEs) in Rural Indonesia
}

\author{
Heru Irianto ${ }^{1}$, Haryono ${ }^{1}$, Dewi Amartanai ${ }^{1}$ J. Andy Hartanto ${ }^{2} \&$ Rr Herini Siti Aisyah ${ }^{3}$ \\ ${ }^{1}$ Universitas Bhayangkara Surabaya, Indonesia \\ ${ }^{2}$ Universitas Narotama Surabaya, Indonesia \\ ${ }^{3}$ Universitas Airlangga, Indonesia \\ Correspondence: Heru Irianto, Universitas Bhayangkara Surabaya, Indonesia. E-mail: heru@ubhara.ac.id
}

Received: October 9, 2018 Accepted: January 7, 2019 Online Published: April 28, 2019

doi:10.5539/par.v8n1p30

URL: http://dx.doi.org/10.5539/par.v8n1p30

\begin{abstract}
The problem of economic empowerment of rural society is very complex because of various rural conditions with various limitations such as education level, skill, and lack of facilities and infrastructures among others are communication means which are expected to be able to bridge to interact in dealing with various problems in rural areas. The means of communication that can reach all the inferior rural areas is community radio. Radio as an information media has a strategic role in synergizing various resources and elements of both the government, private, community, college. Community radio can bring the distance between the various gaps that exist in rural communities. With the program of radio broadcast interactive dialogue will be an educational process to the community because there will be an exchange of ideas and education that can involve many parties and the community umm in solving various problems faced by the community; both in the strategic, tactical and technical levels that are mutually beneficial so that there will be mutualist symbiosis. Thus the sustainability of community economic empowerment activities will be more guaranteed sustainability.
\end{abstract}

Keywords: radio, rural, empowerment, community

\section{Introduction}

Building the nation's economy forward requires at least 2\% or 4.8 million entrepreneurs from the Indonesian population. By comparison, Singapore has an entrepreneurial 7.2\%, Malaysia 2.1\%, Thailand 4.1\%, South Korea $4.0 \%$ and the United States $11.5 \%$ of the total population of Indonesia is estimated to be around $0.24 \%$. The number of entrepreneurs owned by Indonesia is still far behind from other countries (Herman 2013) Indonesia still needs 4.76 million entrepreneurs or about $2 \%$. (http://kabarbisnis.com $/ \mathrm{read} / 2837008$ ) The prolonged multidimensional crisis in Indonesia has impacted the economic pressures of the people, especially the lower classes (Nunung Nurwati, 2006)

To empower rural communities by increasing family income, especially poor families, the need to evaluate errors and solve problems that arise in the family's economic life So it needs to continue to improve its ability to entrepreneurship. (Susanti: 2013) In an effort to empower the community mass communication media have a strategic role because mass communication media does not grow or function in a vacuum. Mass communication media emerge, develop, change and sometimes dying, as a result of geographical, technological, economic, cultural and other influences around it. (Abdul Karim Batubara 2008, 73 -82)

In this study aims to increase the role of community radio as one of the mass media in empowering the economy, the village community so as to empower the people in the economic field, especially the poor communities. Through community radio expected community empowerment is no longer sectoral but with the existence of community radio can provide space and opportunity to all parties to be able to participate hand in hand together mutually beneficial in empowering the village community ..

\section{Literature Review}

The emergence of the idea of community media is actually rooted in criticisms of the liberal mechanistic and linear model of communication approach widely used in the development process. The basic assumption is that the root causes for the third world and its inhabitants (behavior, non-innovative values, low productivity and so on) are 
rooted in the lack of education and information. Consequently the root of the problems facing the third world will be completed if information is improved. On that basis, the existing mass media system then designed the message by default and top to bottom. To develop community radio, there needs to be cooperation between various parties, both government, NGOs and citizens who care about the problems that exist in the community. (Anwarudin, (2010, 1- 78)

The participatory model in development communication in Indonesia does not seem to be a strategy yet. Development of infrastructure provision and not yet accompanied by empowerment using participatory and sustainable models. The effect has not fully demonstrated the level of benefits or outcomes that are changing economic conditions of the community. The communication model for development is a model of micro communications with a community approach and using a participatory communication strategy, it would need to be integrated with development by empowering Information and Communication Tenology for development (Udi Rusadi, 2014, 103)

Community radio normatively provides opportunities for the sustainability of the existence of community radio in Indonesia, for the development and enhancement of the role of community radio is required the support of external forces such as NGO activists, academics and independent institutions and local government so that community radio broadcasts can build participation for community empowerment (Masduki 2004 145-156) Radio as the mass media of electronic communication has some of the power possessed by the radio itself among them: First, maintain mobility. Radio keeps trying to keep listener's mobility high, can be heard without having to stop activity, for example while driving a vehicle, studying, working, and so on. The existence of radio in every opportunity is felt not disturbing. Second, as the fastest information, Radio is the fresh. Compared to print and television media, in addition to faster in the process of serving information and cheaper in its operational process, radio is possible to disseminate information instantaneously. Third, it is auditive. Although it only produces non-visual sounds such as print or visual media such as television, radio is still considered to have an edge. The reason is, the operational process is relatively easier, the operational cost is cheap, besides voice communication has advantages in approach to the listener. Fourth, creating the theater of mind. Production of a radio that is just a sound without pictures, it is able to create 'imagination' that is often tempting to wonder the audience and much more. (Nur 2015. 252-253)

In the economic empowerment of rural communities is still sectoral so that to be effective and efficient need for a synergy of the potential that exists in the area either from the relevant offices or from the private sector so that it can be implemented optimally and solve the problem thoroughly. Due to the situation and condition of the democratic political system that requires the participation of all parties is very necessary (Lismomon Nata, http://sumbar.bkkbn.go.id) To empower families is necessary for the synergy of all parties, both legislative, executive, build cooperation network all good parties including the private sector as well as the importance of family economic empowerment based on local culture. (Sarwirini, 2011: 52) In the economic empowerment of the radio community can bridge the society and the company through Corporate Social Responsibility (CSR) program. The CSR policy in East Java is regulated through Local Regulation No. 4 of 2011 on Corporate Social Responsibility. This regulation regulates the coordination of the implementation of corporate social responsibility (CSR) activities of business actors with stakeholders. However, the implementation is not yet integrated and synergized in terms of programs, implementers and targets that will be the subject of the CSR program. In implementing CSR especially on community development activities should be done with more emphasis on solid and synergic cooperation with other parties, especially the local / local government. (Adlin Hafidza and N Norist, 2011)

The existence of this community radio becomes more and more important when it is associated with local wisdom discourse which is regarded as a key concept of diversity, pluralism and multiculturalism. Issues of local wisdom in Indonesia began to rise and warm discussed when so many local problems that can not be resolved due to the inability of tools solutions globally. In Jamaris research is recommended in empowerment of community group coaching create mutual open, mutual trust, keep each other, in developing family business prosperous and prosperous family I. (Jamaris, 2013). Research suggests that the implementation of family planning will be effective if it is enhanced public access, human resources in government and society, economics and the importance of partnership both local, national and even international because the population problem can not be overcome without involving all parties actively. (Dewi Amartani, 2014) The synergicity of mass media CSR and the community is as well as all stakeholders to take an active role to optimize the implementation of CSR for the prevention of unemployment (Heru Irianto, 20014) 


\section{Research Methods}

This research is related to economic empowerment, village community whose purpose is to encourage people to join in business group to develop their entrepreneurial spirit. This study uses a qualitative approach with multidisciplinary background to assess various economic problems of the village which is further discussed through various events on community radio Role of erlu community radio is optimized for community empowerment, in Ngawi Regency there are 45 community radio this is a very good resource if it can optimized to be a community empowerment agency, especially in rural areas. This research was conducted by Ngawi Regency as a small town west of East Java Region bordering with Central Java Province. As a small town of far-flung rural areas and other large cities most of the people are still poor and marginalized because far from the various facilities that can make it more advanced. The objective of the research is to improve the economics of rural communities through community radio as a medium that bridges various stakeholders who play a role in the economic development of rural communities. Radio is expected to be an agent of community empowerment through interactive dialogue broadcast can provide solution in overcoming various economic problems of rural community Radio as an agent for the empowerment of the poor will have a positive impact on the various sides of the community's life that can end up prospering the village community.

Community radio is selected as a medium for economic empowerment of the community considering the area of the Regency .Ngawi is very wide where the majority of transportation facilities are still inadequate because of the Regency. Ngawi is a rural area far enough out of the reach of the district capital. So in empowering the community have various obstacles and obstacles because of various factors that are very different from urban areas so that radio has a very strategic role. In this research, radio organizes interactive dialogue which invites resource persons, among others from successful entrepreneurs, from various institutions that can assist in solving various economic problems in the village, as well as from universities. With interactive broadcasting it is hoped that dialogue process will take place from various layers a heterogeneous society resulting in an educational process that empowers the community. The family is the smallest community institution but, having a decisive role of successful development of a country if in building a successful family then the development of a more macro society will work as well. Associated with the economic empowerment of rural communities; then the focus of the target is the empowerment of family economy to be able to entrepreneurship by optimizing the potential village available. Thus it is expected to be able to overcome poverty and other problems that can not be separated from economic problems such as education, population and others. Similarly, in addressing the problem of poverty will be successful if focused on the economic development of the family because if the family economy can be improved and improved is expected to be able to improve other sectors of education, In conducting the field research will be conducted in-depth interviews and Focus Group disscussion (FGD). In-depth interviews (Heru Irianto,2001)

\section{Results and Discussion}

Universities will have an important and strategic role to use the Community Development approach in developing MSMEs; because it can involve various stakeholders in the community so that all can participate to synergize in developing their potential optimally. Universities can be initiators, facilitators, motivators, coordinators, counselors in synergizing all stakeholders who want to participate in the development of MSMEs; even as a warehouse of college science will be able to give high contribution so that it can become lokomotiv for progress of MSMEs. Colleges can work with various parties to empower the community. In relation to this research, research has been conducted to empower villagers especially in developing MSMEs by using Community Radio. . Thus expected to happen learning process for people who want to run business. Through community radio, various resources and elements can be optimized to improve the effectiveness of economic empowerment of the community, to synergize these resources then Community radio can bridge various obstacles and distance so that all elements can play and all existing resources can be optimized so that there is synergicity. To synergize the various elements, the community in the economic empowerment of rural communities can simultaneously be applied in an interactive radio dialogue event. This event is a radio broadcast that dialogues the way related to community economic empowerment. In this event invited resource persons to dialogue material which by discussing the problems faced by the villagers, with the radio listeners either community who are members of the community and the general public.

With this event, it is expected that the enumeration will take place together which involves the wider community so that there will be synergy that can optimize all potentials in the community. Community radio has a synergicity role that can accommodate various programs as all parties contribute in solving problems faced by rural communities. Radio as a mass media of communication that can reach all levels of society and the entire region both city and village in a fast without any barriers so it is easier to be able to solve various problems faced by the community in this case is the empowerment of village communities. The advantages of achieving space efficiency, 
and time so as to produce information in a short time and directly dialogue with all levels of society. Therefore, the radio media is very practical and efficient for a medium of media that is information and this is a necessity that can not be negotiable. Growth and development of community radio even more rapidly in line with the increasing needs and awareness of democracy, communication at the local community level. This clearly impacts on various aspects of community life, both economically, socially, politically, and culturally with the educational process in order to be able to find solutions and answer the challenges of various problems that exist in society.

The role of mass media is very strategic to empower the community in order to optimize the local potential to be developed into a product that can be made commodity. With the interactive radio broadcast dialogue can be done various efforts to empower the economy of the village community, especially to encourage the community as an entrepreneur of SMEs.

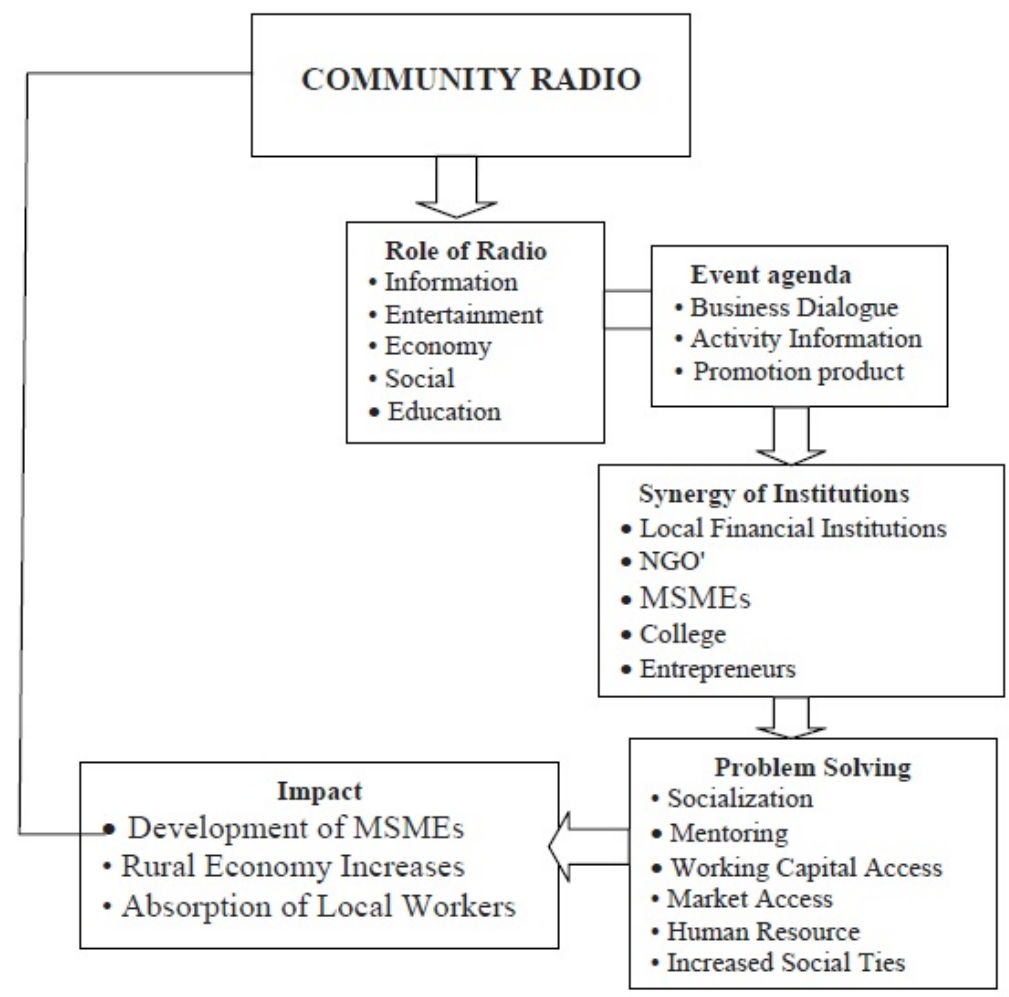

With the radio community so it can be done some ways to encourage people in entrepreneurship, among others: (1) Socialization With the Radio bridging various parties who are interested to participate in the development of products produced by villagers. With this media, it can be socialized together in an interactive broadcast. The socialization was conducted to further introduce the villagers to the village community to provide enlightenment to the community related to the solution to the problems faced by entrepreneurial village communities. With the socialization it is expected that the community will know about the village community related to membership and how if will join in a Small And Micro Enterprises, knowing the development and all problems and prospects of SMEs Socialization means educating the village community that can be expected to provide knowledge and empowerment to the community so as to improve the ability in entrepreneurship. Small And Micro Enterprises as the spearhead, it must be encouraged, especially the spirit to continue to learn to solve business problems that never end. The socialization of village community empowerment is not only involved from the beginning of the program but must be continuously involved in every effort of community economic empowerment conducted by the government. SMEs should be upgraded to be able to provide creative ideas for the community to develop SMEs. (2) Mentoring, With radio broadcasting can also be accompanied by providing solutions for MSMEs who experience barriers in running their business. With the assistance is expected to find solutions to problems faced by MSMEs directly and can be heard by other listeners who have the same problem; so others will be encouraged to entrepreneurship. With interactive radio broadcasting will also encourage community participation to join in the development of MSMEs. With radio broadcasting it can be done in the form of consulting assistance in the form of 
a short time, and if necessary then assistance can be done by visiting or holding regular meetings to follow up various issues that can not be searched through interactive broadcasting events (3) Working Capital Access. Through radio broadcasting it can invite resource persons who can help working capital for MSMEs that require working capital in running their business. With radio broadcasts attract the interest of working capital providers to engage in the Capital MSMEs. Working capital from Telkom, Cooperative. Not only provide working capital but also provide training and assistance to the business undertaken. The availability of working capital without assistance will only make MSMEs fail in running their business. Financial institutions such as banking, cooperatives can provide assistance in the form of working capital for MSMEs that require working capital to run and develop their business. In this case there is a mutualist symbiosis because the financial institution also desperately needs an advanced entrepreneur as a customer while MSMEs requires working capital to support its business. The role of financial institutions by providing soft loans is expected for MSMEs that can grow but experience barriers due to limited working capital. The existence of financial institutions that can provide assistance with low interest loans should be followed up with assistance for Working Capital can be utilized optimally. Working capital is a problem that became the main complaint of most SMEs, as if the availability of working capital is a potent drug to overcome problems in developing SMEs. The location of the problem is not in Working Capital. working capital is important but not the most important, far more important is how to manage working capital. Therefore, it is necessary to develop the capability of the working capital manager from the working capital itself, or if there is providing working capital assistance to MSMEs it is necessary technical assistance how to manage working capital in order to be used efficiently and efficiently. Unable to work capital is only an aid in the form of money alone without accompanied by mentoring. The problem of working capital is not the main problem because when it is offered the working capital of MSMEs does not have the ability to absorb capital because of unpreparedness caused by low skill to produce. (4) Market Access, Market access is the main thing in running every business, because with the market access it means that MSMEs will be able to sell its products. A company can spend as much money to make its products known to the public. For MSMEs would be very heavy if to introduce their products to potential customers by spending a fee. In the market access to MSMEs development through various exhibitions organized by local government and central government, still limited events that are more on serimonial. So that less involving community participation to be more familiar with MSMEs products. It is necessary to have a marketing network for MSMEs that continuously introduce MSMEs products consistently and continuously so that MSMEs products are really known to the public. Thus there is still another effort to market the results of SMEs products such as marketing through social media that can be created together so have a social media one door for MSMEs products specifically. Another media that is appropriate for rural areas is radio, through community radio, people who are members of the MSMEs community can introduce their products to the community without being burdened with high costs. MSMEs owners can also introduce their products as speakers in an interactive dialogue event, which is also an advertisement for its products (5) Human Resource Development In any country Human Resources has an important role in the progress of a country. Associated with the development of SMEs is not free from the role of SMEs in improving the economy of society, especially the bottom layer society. While the lower society there is a tendency to lack the skills to be entrepreneurship, especially to be able to create local potential to generate commodities that can be accepted by the market. To improve the human resources it is necessary that the training program not only train to produce goods or services but also need a comprehensive training, which concerns the mental attitude, work ethic and skill for self-employed so that it is expected to be able to manage its business well it is necessary cooperation or synergicity from various parties. Parties that can cooperate to improve human resources are the employment agencies, colleges, entrepreneurs who have been susceptible. Follow-up of interactive broadcast of resource persons can be done training to MSMES to improve human resources in increasing their business. After the training the development of human resources will improve the skills of members of SMEs and with the increasing skills of members of SMEs can then be followed up by opening a business for MSMEs. MSMES who have advanced also can motivate and consultation for development of MSMES. For MSMEs who want to join in developing SMEs, in this activity will open the opportunity for his business to be more advanced. (6) Increased Social Ties . With the existence of community radio, it will increase the social nodes of the community that can be built in reverse; Especially to empower the community in the economic field and this will increase social integration that will empower the rural economy without losing harmony in community.

\section{Conclusion}

Community radio as an information and education media based on community participation has a strategic role in synergizing various resources whether it is government, private, community, universities, capital providers to be able to empower the community economy through the empowerment of MSMES. . With the program of interactive dialogue broadcast the various problems of SMEs can be solved both in strategic, tactical and technical 
level. Especially for rural areas with the characteristics of rural areas have minimal facilities and infrastructure is not adequate and the skills of people who are still low to become entrepreneurs. With community radio, it can synergize all parties to participate in taking role in accordance with its resources to be able to empower the economy, society with mutualist symbiosis paradigm so that business continuity will be more assured and will be able to help each other and provide solution available to all parties who are involved so that progress can be achieved together to achieve economic development with social justice without losing harmony in community

\section{Acknowledgements}

We would like to thank Kemenristekdikti for this research, we also say to the Rector of Universitas Bhayangkara Surabaya who has given us the opportunity to conduct research, thank you that is also an infinite we also thank the government that has given us the opportunity to work the same in this study

\section{References}

Amartani, D. (2015). Rancangan Model Implementasi Program Keluarga Berencana Di Era Demokrasi Melalui Peningkatan Partisipasi Masyarakat Di Jawa Timur, Hibah Bersaing- DIKTI.

Anwarudin, 2010 Universitas Negeri Islam Kalijaga Yogyakarta, Strategi Pemyiaran Radio Komunitas Dalam Memperoleh Pendengar, 1- 78.

Batubara, A. K. (2008). Pemanfaatan media komunikasi massa Sebagai sumber informasi. Jurnal Iqra', 2(1), 73-82.

Herman. (2013). Retrieved from http://gagasan herman.wordpress.com/2013

Irianto, H. (2001). Metode Penelitian Kulaitatif. PT RajaGrafindo Persada, Jakarta.

Irianto, H. (2014). Rancangan Model Sinergisitas Implemnetasi Kebijakan Corporate Social Responsibility (CSR) Dalam Penanggulangan Pengangguran Terdidik Melalui Program Kewirauasahaan, Penelitian Hibah Bersaing DIKTI.

Jamaris, J. (2013). Pengembangan Model Pembinaan Kelompok UPPKS. Retrieved from http://www.cimbuak.net/artikel/13-artikel-bebas/494-pengembangan-model-pembinaan-kelompok-uppks

LismomonNata. (2012). $\quad$ Retrieved from http://sumbar.bkkbn.go.id/Lists/Artikel/DispForm.aspx?ID=37\&ContentTypeId=0x01003DCABABC04B7 084595DA364423DE7897

Masduki. (2004). Perkembangan dan Problematika Radio Komunitas di Indonesia. Jurnal Ilmu Komunikasi, 1(1), 145-156.

Norist, A. H. (2011). Evluasi Aktivitas dan Pelaporan CSR Studi Kasus PT Xx. Manajemen Usahawan Indonesia, 40(6).

Nur Ahmad, (2015). AT-TABSYIR: Jurnal Komunikasi Penyiaran Islam, 3(2), 252-253.

Nurwati, N. (2006). Survey Dampak Program KB dan Manajemen Pengelolaan Program KB di kota Bandung. Pusat Penelitian Kependudukan dan Pengembangan Sumber Daya Manusia Universitas Pdjadjaran.

Rusadi, U. (2014). Makna Dan Model Komunikasi Pembangunan1 The Meaning And Model Of Development Communication. Jurnal Studi Komunikasi Dan Media, 18(1), 89-104. https://doi.org/10.31445/jskm.2014.180105

Sarwirini. (2011). Rancangan Model Pemberdayaan Keluarga Untuk Mencegah Terjadinya Tindak Kekerasan Dalam Rumah Tangga (Kdrt) Di Jawa Timur.

Susanti, I. (2013). Manfaat Hasil Penyuluhan (UPPKS) Dalam Upaya Pemberdayaan Ekonomi Keluarga. S1 Universitas Pendidikan Indonesia. Retrieved from http://repository.upi.edu/4305/

\section{Copyrights}

Copyright for this article is retained by the author(s), with first publication rights granted to the journal.

This is an open-access article distributed under the terms and conditions of the Creative Commons Attribution license (http://creativecommons.org/licenses/by/4.0/). 